\title{
The prospects of zero-packaging grocery stores to improve the social and environmental impacts of the food supply chain
}

Elisa F. Beitzen-Heineke ${ }^{\mathrm{a}}$, Nazmiye Balta-Ozkan ${ }^{\mathrm{b}, 1}$, Hendrik Reefke ${ }^{\mathrm{c}}$

${ }^{a}$ Dorfstr. 4, 37574 Einbeck, Germany

${ }^{b}$ School of Energy, Environment and Agrifood, Cranfield University, Cranfield, Bedfordshire, MK43 OAL, United Kingdom

c School Of Management, Demand Chain Management, Cranfield University, Cranfield, Bedfordshire MK43 OAL, United Kingdom

\section{Abstract}

Increasing consumer awareness of the environmental and social externalities of food supply chains in developed countries instigates the opening of grocery stores that renounce the use of disposable plastic packaging for their entire product range. The opportunities these novel stores offer in moving to an alternative, more sustainable retail system are currently not well understood. Semi-structured interviews with representatives of seven stores across Europe and six food supply chain experts were conducted in order to address this gap. Findings suggest that these stores may induce more resource-efficient behaviour in suppliers and consumers due to the reduction of packaging and food waste. Social benefits range from the support of small, regional farmers, to higher transparency along the supply chain and better informed consumers. However, these benefits come at the expense of consumer convenience due to slower shopping operations and limited product variety. A wider adoption of zero packaging will require influencing consumer behaviour, convincing suppliers to change their packaging practices, and solving the dependency of food logistics on packaging. In order to achieve wide-ranging, significant environmental and social benefits, zero-packaging stores will ultimately have to

\footnotetext{
${ }^{1}$ Corresponding author: E-mail: n.ozkan@cranfield.ac.uk; Tel: +44 1234 750111, Fax: +44 1234 752971.
} 
offer service levels that are comparable to conventional supermarkets. Potential pathways illustrating how zero-packaging could overcome current market limitations are presented.

\section{Keywords}

Food Retail; Reusable Packaging; Food Supply Chain; Green Business Model; Food Waste; Sustainable Supply Chain 


\section{Introduction}

2 The UK Food Supply Chain (FSC) generated 17.3 million tonnes (Mt) of waste

3 which had an economic value of $£ 19.2$ billion in 2011 (WRAP, 2015). Almost

$490 \%$ of this waste $(15.3 \mathrm{Mt})$ is food waste which accounts for a third of all food

5 purchased. This resembles the trend in the European Union where 88 million

6 tonnes of food with an economic value of 143 billion Euros were wasted in 2012

7 (Stenmarck et al., 2016). Furthermore, the UK FSC emitted $176 \mathrm{Mt}$ of $\mathrm{CO}_{2}$

8 equivalents $\left(\mathrm{CO}_{2} \mathrm{e}\right)$ in 2011. Hence, FSCs in developed countries are generally

9 not sustainable but wasteful (Tassou et al., 2014). Looking to the future, the

10 food industry faces many challenges: By 2030, global demand for food and

11 energy is expected to increase by $50 \%$, leading to a $40 \%$ increase of water use

12 and freight transport (FoodDrinkEurope, 2012).

13 In addressing these challenges in developed countries, Fox and Vorley (2004)

14 recognise supermarkets as the 'gatekeepers' of FSCs. They not only hold the

15 power to induce positive change at both consumer and supplier side but can

16 also pass down their external costs and responsibilities to food processors and

17 farmers. Some measures on how to improve the social and environmental

18 impacts of the food industry have been proposed but "more radical solutions will

19 be needed to reduce further energy demand in the food sector and mitigate the

20 related climate change impacts" (Tassou et al., 2014, p. 163). Fundamental

21 change is necessary, but there is limited research on what such radical

22 solutions might look like and how they can be realised. Most efforts have

23 focussed on individual environmental or social impacts and on optimising rather

24 than rethinking the current system.

25 Even the UK government's ambition to move towards a zero waste economy 26 falls short of its expectations by promoting merely waste reduction and recycling 27 (DEFRA, 2010). As recognised in the waste hierarchy, a better strategy is 28 actually waste prevention (UNEP, 2010). Putting this first principle of the waste 29 hierarchy into practice, a number of grocery stores renouncing disposable 30 plastic packaging have opened across Europe. In these stores, consumers 31 bring their own containers, weigh the tare, fill in the product and pay according 
1 to the weight. The potential of this approach to support the transition towards a 2 low-impact FSC are currently unknown.

3 This paper addresses this gap using Porter and Kramer (2006)'s value chain 4 framework in order to analyse the processes through which these stores 5 provide social and environmental benefits whilst profiting economically. Semi6 structured interviews were conducted with store owners and FSC experts in 7 order to address three key objectives:

1. Analyse and depict the operations at zero-packaging grocery stores;

2. Illustrate the interactions among FSC actors and the influences they have on each other;

3. Assess and evaluate the environmental and social impacts.

12

Whilst we acknowledge that economic impacts (e.g. employment opportunities, revenue generation, and product pricing) are important, they have not been explicitly included in this study. The rationale being that the store concept is novel and any economic analysis at this stage could be misleading due to a lack of long-term data.

The paper is structured as follows: Section 2 reviews the environmental and social impacts of the FSC and contextualizes zero-packaging stores against other alternative food retail concepts. The methodology is discussed in Section 3. Section 4 presents the results from the interviews with both the store owners and experts. Section 5 offers a discussion of the findings while the last section identifies the barriers and drivers for long-term success and scalability of zeropackaging grocery stores.

\section{Framing environmental and social impacts of the food industry}

Environmental impacts focus on emissions, energy and water use, as well as food and packaging waste. Social impacts include food safety, nutrition and ethical trade. We recognise that describing a single exemplary market will provide consistent understanding with regard to the magnitude of environmental 
1 and social impacts of the respective FSC. As a result, we draw examples 2 primarily from the UK, a country of high quality data on food waste (Stenmarck 3 et al., 2016) and supplement this further with information from other comparable

4 markets where relevant. A discussion of the unique position of zero-packaging 5 stores in comparison to alternative food retail concepts like ethical, organic and 6 fair-trade concludes this section.

\section{$7 \quad 2.1$ Environmental impacts}

8 The food industry has changed significantly for both suppliers and consumers in 9 past decades. While in 1954 the product range in a grocery shop was 1,400 10 products, nowadays there are over 30,000 different products (Hayn et al., 2005; 11 J Sainsbury plc, 2016) and in some cases even up to 90,000 (Wood, 2015). 12 Large retailers are highly price-competitive, sourcing food globally and 13 managing their distribution through multi-tier structures. Consumers demand 14 fully stocked stores and a full product range irrespective of the season. 15 Opposing trends towards slow food and eating consciously versus consuming 16 more processed meals (DEFRA, 2006; Kuhn and Sternbeck, 2013) indicate 17 possible consumer trade-offs between the convenience of ready-made meals 18 and home cooking. Additional trends prevalent in Western economies are an 19 ageing population and smaller households, resulting in vastly different 20 consumption patterns. The proportion of single households is rising which 21 generate up to $45 \%$ more food waste per person than the average home. 22 Retailers offer products in smaller packaging, which might reduce food waste 23 but simultaneously increases the packaging per food unit (Akkerman et al., 24 2010; Verghese et al., 2015).

25 A typical retail FSC including packaging practices is presented in Figure 1 with 26 packaging waste highlighted in red. It should be noted that the chain 27 configuration depends on the type of FSC. The FSC of local and unprocessed 28 food is usually less complex and shorter than FSCs of global and processed 29 food products (Smith, 2008). 


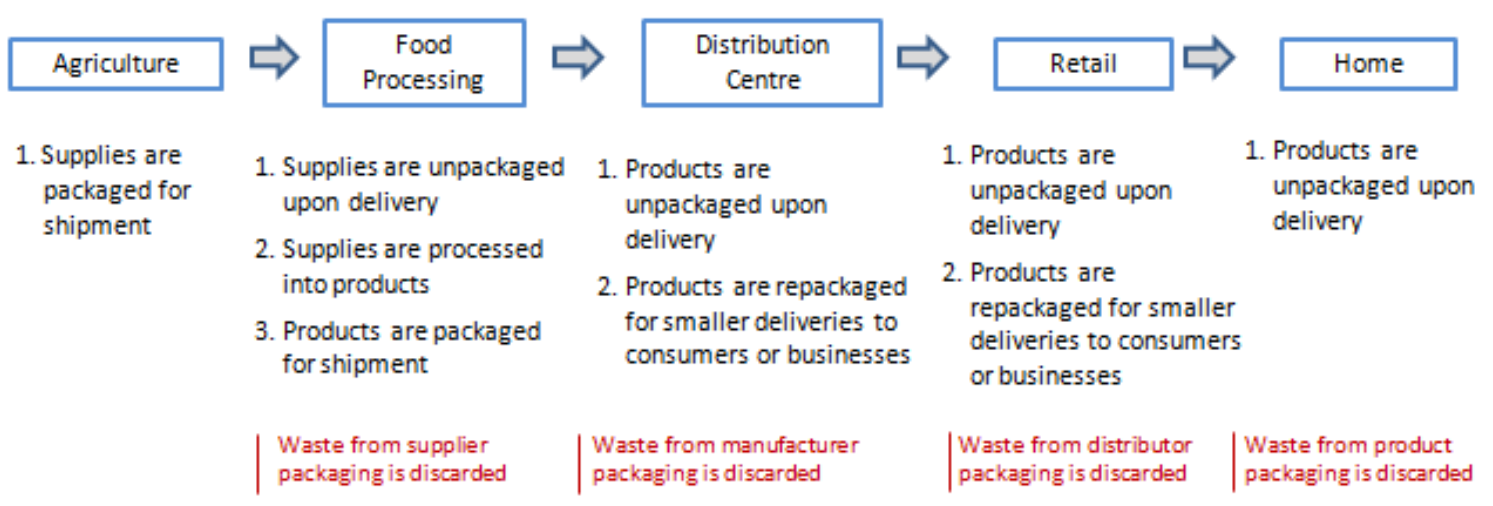

2 Figure 1 Main stages and packaging practices in the FSC

3 Source: Adapted from Naik et al. (2010).

4 In 2011, the UK FSC consumed about $18 \%$ of total primary energy use, 5 generating $115 \mathrm{MtCO}_{2} \mathrm{e}$ (around $21 \%$ of UK emissions, excluding emissions 6 from non-fertiliser pre-farm production, packaging, food waste and land use 7 change). Additionally net trade contributed $61 \mathrm{MtCO}_{2} \mathrm{e}$ (Defra, 2014a; Sneddon 8 et al., 2015).

9 Agricultural production contributes between $47 \%$ and $61 \%$ of greenhouse gas 10 (GHG) emissions related to the FSC (Vermeulen et al., 2012). Other agricultural 11 impacts include biodiversity loss, degradation of fertile land and high water 12 consumption (Baldwin, 2015). Studies suggest that certified organic production 13 consumes $30 \%$ to $50 \%$ less energy due to reduced usage of fertilisers and 14 pesticides. However, this advantage may not be valid per unit of output due to a 15 lower productivity in comparison to intensive production (Garnett et al., 2003).

16 Food processing can be held accountable for high energy consumption, water 17 use and waste generation, driven by an increasing demand for processed and 18 packaged food (Baldwin, 2015; Canning et al., 2010). A life cycle assessment 19 comparison of ready-made and home-made meals reports latter to be more 20 environmentally responsible because of fewer manufacturing stages, less 21 waste, and a decrease in cold storage (Schmidt Rivera et al., 2014).

22 Food transport along the supply chain creates emissions, congestions and air 23 pollution, which contributes to a range of health problems (Baldwin, 2015; 24 Yakovleva, 2007). Refrigeration during transportation results in consumption of 
1 further energy and chemical refrigerants, causing up to $40 \%$ of overall 2 transportation emissions. Transporting frozen food is about 1.7 times more energy-intensive than transporting food at ambient temperature (James and 4 James, 2010). There are two key issues regarding transport. Firstly, shorter transport distances may have fewer impacts, but entire product life cycles need to be considered when assessing impacts. Although generalisations should be made with caution, seasonal and native foods usually have lower carbon foot prints (Akkerman et al., 2010; Saunders and Barber, 2008; Sim et al., 2007;

9 Weber and Matthews, 2008; Wilson, 2007). However, energy intensive production in greenhouses or refrigerated storage is likely to balance out the benefits of short distances. Secondly, the efficiency of the material and product flow is essential (Azevedo et al., 2011). In the UK, around $23 \%$ of vehicles in FSCs drive empty (Garnett et al., 2003) whilst more frequent deliveries with smaller quantities lead to higher emissions. Hence, instead of focusing on food miles, it is suggested that product assessment should look at "the carbon emission per unit of produce over the transport chain" (Coley et al., 2009, p. 154). Using this approach, it is clear that the last mile, i.e. the shopping trip of the consumer, causes high emissions per product (Gevaers et al., 2014; Seebauer et al., 2015). While many large companies already manage their fleet via decision support and information systems (Akkerman, et al., 2010), increasing the sustainability of supply chain logistics remains an on-going research area of international efforts ${ }^{2}$. Food retail does not contribute significantly to the overall energy use of the food industry, but nevertheless has potential to reduce its environmental impacts by recovering heat and using renewable energy systems in refrigeration (Tassou, 2014).

26 Emitting $18 \mathrm{MtCO}_{2} \mathrm{e}$ yearly, UK households including catering facilities are the second biggest contributors to the GHG emissions of the food industry (Defra, 2014a). Recognising the role of dietary habits and lifestyle choices, including increasing demand for meat products and convenience food, some scholars

\footnotetext{
${ }^{2}$ Among this, Step Change in Agri-food Logistics Ecosystems (SCALE) project aims to establish different tools and frameworks to increase efficiency and sustainability of supply chain logistics.
} 
1 argue that a change in diet would be the most sustainable solution (Garnett, 2 2011). On the other hand, households are also the principal contributor of food 3 waste (7.2 Mt, accounting for $46 \%$ of total food waste), followed by 4 manufacturing (26\%), whereas grocery retail and wholesale generate only $2.9 \%$ 5 food waste (Defra, 2014b). Overall, $75 \%$ of the food waste, and hence 6 emissions related to food production, transportation, and processing could be 7 avoided (WRAP, 2015). For this reason, Rivera et al. (2014, p.308) claim that 8 food waste "is the single most important factor for reducing the environmental 9 impacts of food'. A study by WRAP (Waste and Resources Action Programme) found that food not being used in time is the main reason for food waste 11 (Quested et al., 2013). In this context Verghese et al. (2015) state that 12 packaging helps to decrease food waste along the supply chain by reducing 13 damage in transport and handling as well as prolonging shelf life.

14 Packaging provides several functions: Protection, utility and communication in 15 physical, atmospheric and human environments. This includes containment to avoid leakage and loss, safe and efficient transportation, as well as convenience and attraction of consumers (Risch, 2009). While packaging provides these functionalities, the global FSC also accounts for about $70 \%$ of packaging waste (Emblem and Emblem, 2012). Furthermore, packaging is responsible for 7\% of the UK food-related GHG emissions (Garnett et al., 2003). Plastic production uses approximately $8 \%$ of global oil production which is also causing adverse environmental effects. One third of all food packaging is produced for short time use only, even though it is unclear how many hundreds of years plastic needs to fully degrade (Koelmans et al., 2014; Roy et al., 2009). 25 Jambeck et al. (2015) calculated that about $2-5 \%$ of the $275 \mathrm{Mt}$ of plastic waste generated in 192 coastal countries ended up as marine debris in 2010. Increases in this plastic debris are of course correlated with the increasing 28 occurrence of single-use products and disposable packaging (Thompson et al., 2009). As recycling only treats the symptoms and is rather costly due to separation and sorting of waste materials, prevention and re-use has the 
1 highest priority in literature and legislation ${ }^{3}$ (Bartl, 2014; Emblem and Emblem, 2 2012). WRAP and major UK grocery organisations have agreed upon the 3 Courtauld Commitment, setting a voluntary target for the grocery sector to 4 reduce food, product and packaging waste by $1.1 \mathrm{Mt}$ by 2015 which could 5 potentially save the industry and consumers $£ 1.6$ billion (DEFRA, 2013; WRAP, 6 2015).

7 The protection provided by food packaging serves an important function. Figure 82 shows the total energy inputs for a person's weekly consumption of food. 9 While packaging accounts for approximately $10 \%$ of the total energy input, it 10 ultimately protects the other $90 \%$ that could have gone to waste without 11 protective packaging (Verghese et al., 2015).

$$
51 \%
$$
$10 \%$ $8 \%$ $17 \%$ $14 \%$

Food supply $\Rightarrow$ All Packaging $\Rightarrow$ Transport $\Rightarrow$ Storage $\Rightarrow \Rightarrow$ Cooking

Figure 2 Relative energy consumption for a person's weekly food intake

14 Source: Adapted from Verghese et al. (2015)

\section{$15 \quad 2.2$ Social impacts}

16 Food production and consumption have several direct impacts on society. On 17 the supply side, cheap food prices in Europe may have negative impacts on the livelihoods of small-scale producers in developing countries. Ethical trade initiatives exist to counteract this issue (e.g. the UK Fairtrade Foundation), ensuring fair prices for producers in developing countries (Baldwin, 2015). Yet, small-scale farmers in developed countries also suffer from market powers of large supermarkets ${ }^{4}$. For example, only four large retail companies make up about three quarters of the UK market (Steedman and Falk, 2009). These large market players use economies of scale to exert downward pressure on prices.

\footnotetext{
${ }^{3}$ European directive 94/62/EC on packaging and packaging waste introduces minimum recovering (at $60 \%$ ) and recycling (at $55 \%$ ) targets to be achieved by 2008 , which have been revised subsequently.

${ }^{4}$ In the UK, as of January 2016, one of the large supermarkets is being investigated for deferral of payments to its suppliers, breaching the industry's code of conduct to protect grocery suppliers (http://www.bbc.co.uk/news/business-35408064).
} 
1 As a result, energy-using machinery has in many cases substituted human 2 labour. Not only does this increase food-related energy use, but it also creates 3 further pressures on small-scale farmers all over the world as they cannot afford 4 investments in new technologies (Canning et al., 2010; Pimbert et al., 2006). 5 Whilst a lack of data does not allow the UK government (in particular 6 Department for Environment, Food and Rural Affairs, DEFRA) to identify 7 structural changes in the UK agribusiness (Langton, 2015), Germany has seen 8 a decrease in the number of farms of $20.6 \%$ between 1999 to 2007 while the 9 number of employees reduced by 12.9\% (BMELV, 2010). Concentration of market power at few major food corporations and retailers means they gain the 11 most profit in the FSC (Pimbert et al., 2006).

12 Concerns about food safety have also been increasing. In 2006, approximately 13450 people died from foodborne illnesses in the UK (DEFRA, 2006). Food safety can be increased by providing physical protection through packaging. This prevents contamination while the protective atmosphere surrounding the food inhibits bacteria growth (Davis, 2013). Food safety is furthermore impacted by complex supply chains which make it difficult to trace individual product inputs (Wognum et al., 2011). This lack of transparency is an important issue for customers, $84 \%$ of whom mistrust the products they buy and are willing to pay more for ethical and safe alternatives. They are concerned about the correctness of certification (fair trade, eco, UTZ, rainforest alliance, etc.), treatment of animals, conservation of natural resources and minimising pollution and packaging (Co-op, 2004).

24 Another issue relevant to both policy makers and consumers is over- and 25 undernourishment. While over 1.5 billion people are either overweight or obese 26 globally, one billion are hungry and malnourished (Baldwin, 2015). Focusing on the nutrition in developed countries, in the UK for example, $65 \%$ of men and $56 \%$ of women, equal to 24 million adults, are overweight or obese. An unhealthy diet consists of high consumption of saturated fat, salt and sugar, which are especially found in processed foods, and low intake of fruits and vegetables. There are various obstacles to maintaining a well-balanced diet. 
1 Even in Western societies many people live in poverty and cannot afford a 2 healthy diet. Food labelling and marketing is incomprehensive and misleading, 3 inhibiting truthful education and information transfer. A consumer survey 4 showed that the majority of Europeans find eating healthy challenging and $90 \%$ 5 of Britons would appreciate retailers to simplify a healthy diet (Mwatsama and 6 Stewart, 2005; Smith, 2008).

\section{$7 \quad 2.3$ Positioning of zero-packaging stores}

8 There are several well established alternative food retail concepts that aim to 9 address the aforementioned environmental and social impacts. In addition to conventional supermarkets, these alternative retail concepts include organic food, ethical sourcing and fair trade, regional sourcing, and also neighbourhood or local stores. As mentioned, conventional supermarkets carry large product assortments, e.g. potentially up to 90,000 stock keeping units (Wood, 2015), and the associated distribution activities depend on food packaging in order to facilitate trade and transport of food products (Risch, 2009). Organic food is characterised by particular production standards, i.e. more natural methods of growing and harvesting crops as well as avoidance of chemicals, and is generally certified by a certification authority (ISTF, 2016). Ethical sourcing and fair trade aim to embed improved environmental and social standards into production and distribution and compensate the producers fairly (Raynolds, 2000). Regional sourcing is primarily concerned with established local food supply chains, thereby reducing transportation requirements and supporting local producers (Smith, 2008). Lastly, neighbourhood or local stores emphasise proximity to the final customer and hence convenience. Proximity to the endcustomer may reduce the 'last mile', which is generally associated with a significant environmental impact (Edwards et al., 2010).

27 A classification framework of these different food retail concepts is developed in 28 Table 1 which identifies the core attributes commonly connected to each of the food retail concepts introduced. These attributes can be likened to the decisive competitive criteria that a store concept exhibits, i.e. order winners. These criteria can win customer orders against competitive offerings in the same 
1 market (Hill and Hill, 2012). It needs to be emphasised that the connections 2 drawn here are indicative and cannot capture the unique characteristics of 3 individual stores. Actual stores may in fact exhibit the attributes from multiple 4 concepts and hence appeal to customers through multiple order winning 5 criteria. Nevertheless, it offers an insightful overview that captures essential 6 attributes of different store concepts.

7 
1 Table 1 Indicative summary of core attributes of alternative food retail concepts

\begin{tabular}{|l|c|c|c|c|c|c|c|}
\hline $\begin{array}{l}\text { Store } \\
\text { Concept }\end{array}$ & $\begin{array}{c}\text { Conve- } \\
\text { nience }\end{array}$ & $\begin{array}{c}\text { Ethical } \\
\text { Sourcing }\end{array}$ & $\begin{array}{c}\text { Environ- } \\
\text { mental } \\
\text { Protection }\end{array}$ & $\begin{array}{c}\text { Health } \\
\text { Benefits }\end{array}$ & $\begin{array}{c}\text { Packaging } \\
\text { Reduction }\end{array}$ & $\begin{array}{c}\text { Product } \\
\text { Selection }\end{array}$ & $\begin{array}{c}\text { Transport } \\
\text { Reduction }\end{array}$ \\
\hline $\begin{array}{l}\text { Conventional } \\
\text { Supermarket }\end{array}$ & $\checkmark$ & & & & & $\checkmark$ & \\
\hline $\begin{array}{l}\text { Ethical / Fair } \\
\text { Trade }\end{array}$ & & $\checkmark$ & & & & & \\
\hline $\begin{array}{l}\text { Neighbour- } \\
\text { hood Stores }\end{array}$ & $\checkmark$ & & & & & & $\checkmark$ \\
\hline $\begin{array}{l}\text { Organic } \\
\text { food }\end{array}$ & & & $\checkmark$ & $\checkmark$ & & & \\
\hline $\begin{array}{l}\text { Regional } \\
\text { Sourcing }\end{array}$ & & $\checkmark$ & & & & & $\checkmark$ \\
\hline $\begin{array}{l}\text { Zero- } \\
\text { packaging }\end{array}$ & & & $\checkmark$ & & $\checkmark$ & & \\
\hline
\end{tabular}

\section{Methodology}

3 Porter and Kramer (2006) and Wognum et al. (2011) argue that it is inefficient

4 for businesses to deal with their business strategy and their economic and

5 social performance separately. The integration of these impacts into their

6 strategic long-term goals would unfold "opportunity, innovation, and competitive

7 advantage" (Porter and Kramer, 2006, p. 1) which are the guiding principles of

8 zero-packaging grocery stores. Hence, in analysing how zero-packaging

9 grocery stores integrate their environmental and social performance into their

10 business concept, we follow Porter and Kramer's (2006) strategic framework.

11 Their strategic framework aims to enable businesses to identify their

12 externalities, integrate them into their strategic long-term goals and quantify

13 their benefits. They separate the business activities into primary (Inbound

14 Logistics, Operations, Outbound Logistics, Marketing and Sales, and After-

15 Sales Service) and support activities (procurement, technology development,

16 human resource management and firm infrastructure). In this study, inbound 17 and outbound logistics are combined due to the small scale of the stores under 18 investigation. Furthermore, firm infrastructure and human resources can be 19 regarded as less relevant at this stage. After-sales service in a conventional 20 sense does also not apply and is not included in the study. Excluding these 21 areas will not necessarily reduce the value of utilising the framework as Porter 22 and Kramer (2006) recognise that companies cannot target each of these 
1 areas. Instead they could select a few social initiatives such as customer 2 information, truthful advertising, emissions and waste that benefit both society 3 and their own competitiveness. In our analysis, we separate identified benefits 4 into social and environmental categories as the former refers to favourable 5 impacts on people whereas the latter to those on the planet. Using Porter and 6 Kramer's (2006) value chain framework (Figure 3) we analyse through which 7 processes zero-packaging stores provide social and environmental benefits 8 whilst achieving gains for their business.

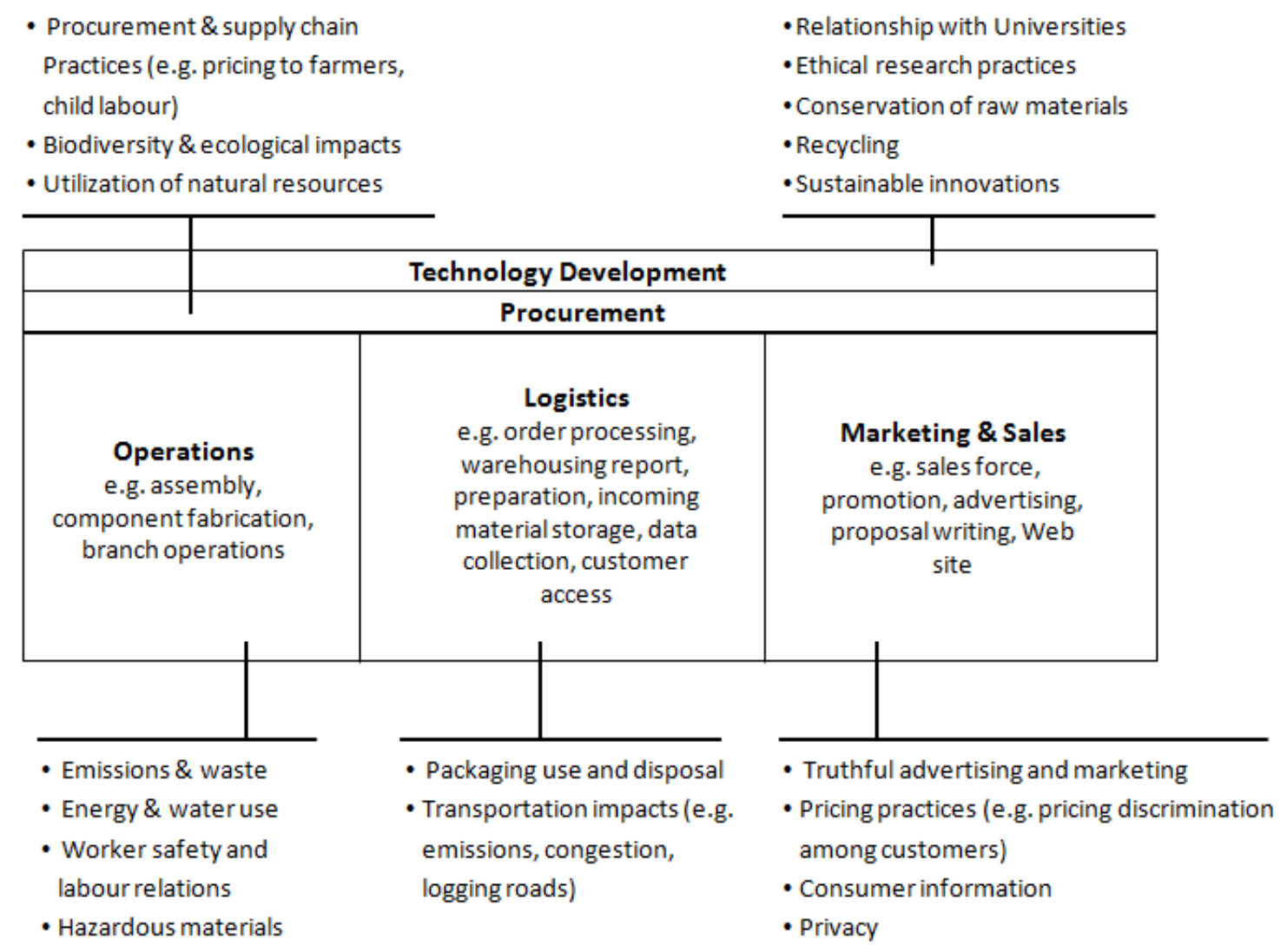

10 Figure 3 Social and environmental value maximising business concept of zero11 packaging stores

12 Source: Adapted from Porter and Kramer (2006)

13 The methodological approach followed is depicted in Figure 4. In order to 14 identify zero-packaging grocery stores, a documentary analysis of websites, 15 videos and newspaper articles was undertaken. In parallel, a literature review 16 was targeted at understanding the environmental and social impacts of current 17 FSCs and at identifying key research questions and knowledge gaps related to 
1 a more sustainable food industry. Semi-structured interviews with store owners 2 and managers as well as domain experts were conducted in order to capture a 3 wide range of views whilst generating comparable results. Interviews with the $4 \quad$ FSC experts were used to contextualise the findings of the store interviews and 5 identify the barriers and drivers that zero-packaging stores are facing.

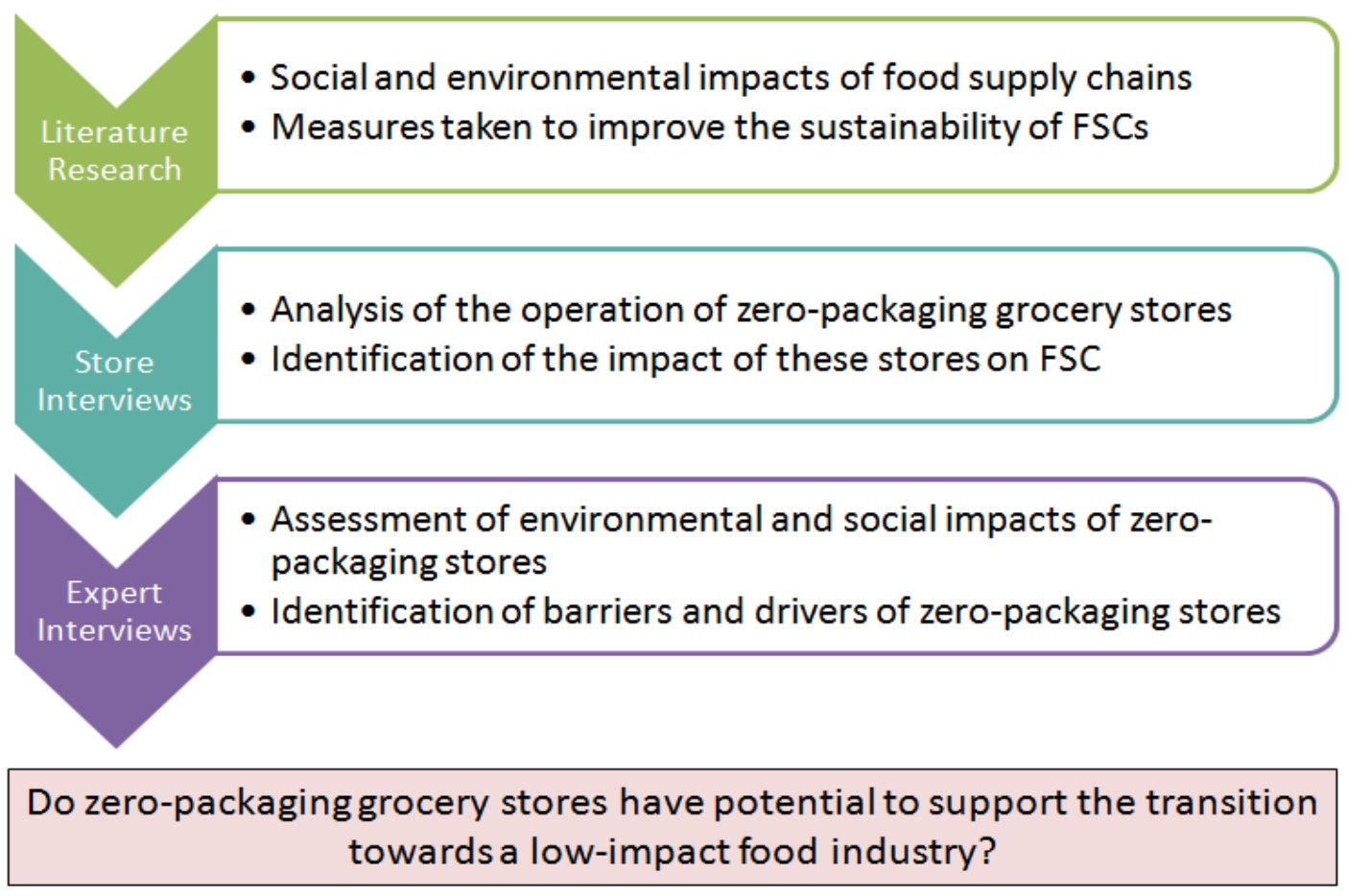

$7 \quad$ Figure 4 Methodology and key research question

\section{$8 \quad 3.1$ Store interviews}

9 In order to identify zero-packaging stores operating in Europe and North 10 America, a web-based search in English and German was performed. As of 11 July 2015, 19 operating stores were found that are located in Europe and North 12 America. Seven are about to open and there are various stores with 13 departments that offer unpackaged products. It should be acknowledged that a 14 number of unknown cases are likely since many stores may not have a web 15 presence or were not found due to language barriers. A detailed list of the 16 identified stores is provided in Appendix A. While one store dates back to 1885, 17 the rapid emergence of the stores started in 2014. One reason for the recent development is that these stores use crowdfunding to raise initial financial 
1 capital. Hence, the concept received worldwide attention and motivated people 2 to open their own store. Due to their innovative business models, two stores 3 that had not yet opened were also included in the study. Altogether, 21 stores 4 were asked to participate in the research in a personalized email request, 5 including a short information sheet and the questionnaire. Seven stores, located across Germany, Austria and Italy, agreed, yielding a participation rate of $33.34 \%$. Six respondents are store owners, while one respondent belongs to

8 the store management team. Several stores cited lack of time as a reason for non-participation. Four phone interviews were conducted, while three stores preferred to complete the questionnaire in written form. It has to be considered 11 that qualitative research is generally not about representativeness but rather 12 aims to "generalize from and about cases across a range of cases" 13 (Sandelowski and Barroso, 2007, p. 5). The interviews were guided via a 14 questionnaire framework, but additional, non-predefined questions were raised 15 for clarification and more in-depth information. The interviews were recorded, translated to English (if necessary), and transcribed. It was furthermore checked whether questions were neutral and that the interviewer did not influence answers through implied opinions or judgements. As the majority of the interviews were performed over the phone, non-verbal behaviour could not be observed (Robson, 2002). The interviews were analysed using thematic coding as explained in Rubin and Rubin (2005). There was one main analyst and results were double checked with two more researchers. In the results, the store respondents will not be further classified as it could compromise their anonymity.

\subsection{Expert interviews}

26 An expert was defined as someone who has been working in the food industry 27 or conducting research about food sustainability or FSC management for at least seven years. The experts were identified through relevant literature, web based search and snowballing method. 22 experts were contacted with a personalized email request, including a short information sheet and the questionnaire. Six experts agreed to participate in the research. They have 7 to 
123 years of experience in research and/ or the food industry (Table 2). The 2 interviews took between 45 and 60 minutes. One interview was shortened to 15 3 minutes because of time constraints. The interviews were analysed with the 4 same method as those with store owners.

5

6 Table 2 Key characteristics of experts

\begin{tabular}{|l|c|c|c|}
\hline \multicolumn{1}{|c|}{ Field of Research } & \multicolumn{3}{c|}{ Years of Experience } \\
\cline { 2 - 4 } & $5-9$ & $10-19$ & $20+$ \\
\hline Collaborative and sustainable supply chain management & $\checkmark$ & & \\
\hline $\begin{array}{l}\text { Agri-food supply chain management } \\
\text { Work experience in the food industry }\end{array}$ & & & $\checkmark$ \\
\hline Optimisation of supply chain management & & $\checkmark$ & \\
\hline $\begin{array}{l}\text { Supply chain management } \\
\text { Food supply chain management* }\end{array}$ & & & $\checkmark$ \\
\hline Food supply chain management & $\checkmark$ & & \\
\hline Food Science and Supply Chain Management & & $\checkmark$ & \\
\hline
\end{tabular}

$7 \quad$ *10 years of experience was reported in food supply chain management

\section{Results}

9 In order to analyse the zero-packaging stores' business concepts and their 10 social and environmental impacts holistically, we present our findings using 11 Porter and Kramer (2006)'s framework. Findings from the store interviews are 12 followed by those from the domain experts.

\section{$13 \quad 4.1$ Store interviews}

\section{$14 \quad$ 4.1.1 Operations}

15 The seven stores that were interviewed for this study offer products free from 16 disposable packaging: dry products (wheat, pasta, rice, lentils, etc.) in bulk bins; 17 yoghurt, milk or jam in reusable glass jars or bottles and some also offer soap, 18 shampoo, etc. Except for two stores, all offer fruits and vegetables. Some stores 19 offer cheese, meat and fish at a refrigerated counter by trained staff, which is 20 too expensive for other stores. Others are located next to a butcher or cheese 
1 shop. The customers bring and weigh their containers and pay for their

2 purchase based on its weight. Generally, store owners mentioned that in-store 3 operations are more time-consuming and ideally customers need to plan ahead 4 and provide the different containers they will need for their purchase. However, store respondent (SR) 1 argued that this is not necessarily a weakness but rather a strength of the store concept as it increases the appreciation for the 7 food.

8 Product variety is considerably smaller than in conventional supermarkets, 9 ranging from 300 to 1500 products. They offer some convenience products 10 such as jam, pasta, sweets and sauces, but generally do not sell processed or 11 frozen food. Overall, they want to "correspond to the day-to-day needs of the 12 customers" and claim that "the combination (of different produce in the meals) is 13 the diversity" rather than the mere number of products stacked in the shelves 14 (SR 1 and 4). SR 6 highlighted the importance of offering products that are consumed frequently to avoid food waste.

16 Five stores claimed to offer a very different shopping experience compared to 17 conventional food stores: less stressful, better consultation and customers see and try the product. They "want to prioritise the human again" (SR 2). Three stores also have a small coffee or a snack counter in the store.

20 One store offers exclusive nutrition counselling, cooking workshops and 'recipe 21 boxes', containing assembled raw materials for further preparation at home. 22 The owner emphasised that by buying the recipe boxes, the customers would notice how big a portion actually is.

24 Another core characteristic of the stores highlighted by all correspondents is the 25 small amount of food waste they produce, which is often included in their business pillars. The stores either i) donate perishing foods ii) process unsold food and sell their products for example in a counter lunch, café or catering, or iii) process it for personal use:

"Ultimately, we are deciding which products are used in the counter lunch as well as in the recipe boxes. That is why we are able to steer the product 
1 demand, even if products are not purchased by customers. This is another 2 aspect, where unpackaged is a benefit. We are able to use the food products 3 from our supermarket. Our model is a building block system. Large 4 supermarkets cannot or are not allowed to do that" (SR 4).

5 Furthermore, people are more likely to buy only the amounts they need which, 6 according to the store owners, reduces food waste at the consumer-end. SR 4 7 also suggests that fewer customers buy goods ahead of time nowadays. The 8 stores with gastronomy stated that they generate little food waste. Their focus is on preventing the disposal of food due to reaching their best-before date, even though they are still edible.

11 Regarding food safety, all stores follow the hygiene regulations applicable. Meat and cheese require refrigeration and only some stores are thus able to offer them. Several stores mentioned that they work closely with hygiene regulation offices. Furthermore, they generally have to pay closer attention to the condition of products on offer. Most of the stores also remind customers on their websites to clean their containers in order to prevent contamination.

\section{$17 \quad$ 4.1.2 Logistics}

18 For most zero-packaging stores, products are delivered by different suppliers and they do not manage the inbound logistics. Only one store is planning to pick up some of the fresh products from small and medium size suppliers with their electric vehicle. Several stores are designed as a franchising concept, yet only one had already established multiple stores. Managing a central and a local warehouse for their distribution, they do not focus on regional products. Four other stores offer delivery services, which are mainly run by bicycles, electric bicycles and electric cars.

The main difference from the conventional grocery stores is the prevention of packaging waste at the consumer-end. Packaging waste will be discussed in detail in the section on Procurement (4.1.4). Overall, disposable packaging is limited to paper bags which are available in most of the stores for customers not bringing their own containers. One store uses stronger paper bags which can 
1 be reused 10 to 20 times. Regarding packaging waste, the stores mainly 2 generate paper and carton waste and some plastic foil. The focus is on 3 reusable containers to avoid resources and emissions for the production, 4 recycling and disposal of the packaging material. In case of suppliers that do 5 not reuse containers, several store operators reuse them internally or 6 endeavour to find alternative use.

7 Only one store had already collected data about their packaging savings, but 8 most stores are planning to do so in the future: "In one year, the elimination of 9 the packages on the sales of wine and detergent brings an overall saving of resources equal to $104290 \mathrm{kWh}$ of energy, 34 tonnes of $\mathrm{CO}_{2}$ emission in the atmosphere and more than 9.8 million litres of water that were not used for the production and disposal of packaging in excess" (SR 5).

\subsubsection{Marketing and sales}

Another key difference to conventional supermarkets is that none of the interviewed zero-packaging stores offer different brands of the same product as "Products have to be protagonists. There are no labels and no brands" (SR 5). SR 4 expressed that "today's grocery shopping is just not contemporary anymore. It does not respond to the individual needs of the customer. No packaging helps to respond to their needs by reducing the 'food confusion' caused by brands, packaging, product information and false advertising."

One store explicitly said that their advertisement is honest compared to conventional stores. Store 7 advises their customers to wisely choose the portion size and rather come back for more. Jointly with their suppliers, they organise events like lectures on sustainability and cooking workshops to increase customer awareness. Being consistent with their priority to be transparent, they provide information about their suppliers. One store plans to reveal how much the producer eventually receives of the product price.

Two stores aim to inform their customers about the emissions they have saved by renouncing disposable packaging via an application run on mobile devices or 
1 a sustainability index on their website. By offering these services they claim to 2 increase the environmental awareness of their consumers.

3 The price difference to conventional supermarkets varies. Some stores

4 mentioned a price reduction of up to $12 € / \mathrm{kg}$ due to buying the products in big 5 bags. The producer saves packaging and marketing costs. Therefore, most of 6 them can sell their products cheaper than organic supermarkets. Yet, this was 7 contradicted by one store who said that they could not observe a great price 8 difference to packaged products. Yet, another store which does not focus on 9 regional products said consumers could save between $30-70 \%$ on average compared to buying an equivalent packaged product. By purchasing only the amounts needed, customers are flexible and can buy a greater variety of products with the same or lower expenditure. Different stores embrace their social goals by i) helping people to maintain a healthy diet at a reasonable cost, ii) making organic products accessible to a wide range of consumer groups, and iii) trying to offer products for every class of society. Therefore, one store offers basic products at competitive prices, made possible by the direct transfer of material and transportation cost savings onto the product price. Remaining products are more expensive and consist of delicacies, such as self-developed baking goods. When asked about the price comparison, one SR argued that avoided environmental costs should be considered as well.

\subsubsection{Procurement}

Different criteria dominate the supplier selection on packaging, organic production, regional origin and fair-trade.

Zero-packaging stores save disposable packaging at the consumer end, but three of the stores stated that due to their small purchasing power, they do not have an impact on packaging practices of the suppliers. They receive their products in big bundles and bags (e.g. 25kg for rice or $1 \mathrm{~kg}$ for spices). The majority has a mixture of reusable and recyclable waste (cardboard, paper) and some a minimum amount of disposable plastic foil, which is wrapped around the pallets due to transportation regulation, or plastic bags for products such as chocolate and nuts. Still, most SRs claim that having a little disposable 
1 packaging waste from the suppliers does not balance out the immense 2 disposable waste savings at the consumer end. Yet, one SR is adamant not to accept any products delivered in disposable packaging:

4 "Every time they get the feeling that it [the negotiation] is getting strenuous or 5 that the supplier does not want to change their logistics, they should leave. [...] 6 And they [the suppliers] return on their own or they are just not the right supplier 7 for you. I rather renounce a product, before it is getting strenuous" (SR 1).

8 While two respondents acknowledged that many suppliers are actually already 9 working with reusable packaging, others highlighted this as a barrier as there 10 are not many suppliers that can deliver the products in big bags. Especially 11 organic products are not available in big bundles. Therefore, the range and 12 quantity of suppliers depends on the region and the criteria stores impose upon 13 the suppliers, e.g. no plastic packaging, being in direct vicinity, using fair trade 14 products or organic production methods.

15 Two of the interviewed stores offer only organic products while the other five also provide non-organic ones. The former group think organic products to be ecologically valuable and healthier for both the consumers and the farmers. Stores in Germany and Austria in particular emphasise organic products. In general, the stores procure from smaller and medium farms directly as they are not only more likely to change their packaging practices but will also help to keep the transport distances as short as possible. Using regional products is a priority for five stores with one store procuring products only within a $100 \mathrm{~km}$ 23 radius:

"We would like to offer an extensive vegetable and fruit assortment all year long. But this is, for us and our philosophy, in no relation to the distances and the effort that would have to be undertaken to offer it. This is why we decided to offer seasonal fresh produce. Then, you cannot compete with the big supermarket chains, but in return we are honest" (SR 2).

Despite the aim to procure from the closest suppliers possible, in practice many stores cannot completely adhere to this criterion as they do want to offer 
1 specific products such as bananas (if offered, mainly organic and fair-trade) or

2 tomatoes during winter season.

\section{$3 \quad$ 4.1.5 Technology development}

4 Removing packaging requires innovative ways of weighing and paying for 5

\subsection{Expert Interviews}

Regarding the environmental impacts of the FSC, one expert acknowledged that even though packaging is not the biggest emitter, it "is the easiest element that we can work on. Because you need to grow food, those emissions are unavoidable" (Expert 12). The experts described that large retailers decide upon the packaging design to optimize promotion and distribution. Marketing can cause more material use than actually necessary for protecting the food. Expert 12 suggests that conventional stores are externalising their problems since customers have to dispose of packaging and pay a council tax for waste management. Moreover, suppliers have to comply with standardized packaging guidelines of conventional supermarkets, limiting process innovation.

\subsubsection{Operations}

Several experts reflected on inconveniences zero-packaging grocery stores place on their customers. This inconvenience stems from a more timeconsuming shopping experience, limited product range and that containers would have to be carried around all day if people wanted to shop after work. 
1 The experts identified further risks that can arise from shopping practices in 2 these stores. Customers not cleaning their containers properly and crosscontamination were mentioned as potential food safety risks. However, these could be prevented by educating people. Considering the store management, an expert concluded that there are no concerns that could not be solved with technology development.

\section{$7 \quad$ 4.2.2 Logistics}

8 Supply chain experts emphasized that the efficiency of distribution does

9 generally not depend on the size of the store but rather on the logistics system. 10 Hence, different packaging design or less packaging would influence 11 transportation and distribution related emissions. Less packaging would make the transport lighter and enable the distributors to ship more products, reducing overall energy consumption per unit. However, the missing protective function of packaging during transport and distribution needs to be addressed.

\subsubsection{Marketing and sales}

Various experts view the stores' claim to reduce food waste at demand side to be very profound in particular. This is because they do not tempt customers to consume more than required with promotional activities used by conventional supermarkets such as "buy 1, get 1 free" or larger family-packages. Nonetheless, the experts cautioned against other potential sources of food waste: Firstly, fruits usually perish earlier if they are not packaged and are exposed to other perishing fruits. Secondly, consumers are used to products with a long shelf life. Consumers would have to adapt accordingly as they will otherwise generate more food waste.

While three experts did not see a direct influence of zero-packaging grocery stores on the diets of the costumers, two experts identified positive impacts. They highlighted the substitution of processed foods with self-cooked meals, the different shopping experience, marketing and engagement with the food:

"If they sell the right foods and people know how to cook, there are enough products there to be able to provide good and healthy meals. Probably we 
1 would avoid obesity and problems like that. [...] And I think [...] they won't be 2 influenced by the offers, the pressure and the end-of-peer promotions, etc., they 3 won't take home food they don't need." (Expert 11).

\section{$4 \quad$ 4.2.4 Procurement}

5 The 'dysfunctionality of the supply chain' (Expert 13) where retail practices players.

\subsection{Contextualising social and environmental impacts of zero- packaging stores}

20 Expert 14, also working on climate change, explained three key considerations for a sustainable food system: climate adapted production of food, reduction of food waste along the supply chain and shifting towards a low-emitting consumption. As the zero-packaging stores positively impact the two latter areas, they could potentially have a significant impact if they were able to reach scale. This would principally depend on product prices, followed by convenience and thirdly environmental benefits. This expert argued that the majority of consumers are not willing to pay more for a less convenient shopping experience because of an improved environmental performance. On the other hand, experts also noted that people are becoming more environmentally aware and that there is a consumer niche that prioritises environmental performance. 
1 Yet, reaching scale could also lead to new barriers as "supermarkets would fight 2 back and possibly try to persuade governments that there are food safety and 3 technological reasons not to allow it" (Expert 11). However, Expert 14 4 emphasised that the expansion of small stores is not going to be sufficient and 5 that large retailers need to adapt zero-packaging practices as well. As this 6 system fundamentally changes consumer-brand relationships and operations of 7 large retailers, government incentives and regulations are needed to convince 8 large retailers. For example, since May 2015 France forces retailers to donate 9 or process unsold food (N24, 2015). Also, UK supermarkets reported significant reductions in plastic bag usage since the introduction of a 5 pence charge for all

11 single-use plastic bags in October 2015 (The Guardian, 2015).

12 Overall, experts have highlighted many positive outcomes these stores stand to 13 provide by offering products without packaging, enabling consumers to control 14 product portions and focusing on healthier nutrition. Yet, the scope and 15 16 widely.

17 Table 2 presents a detailed overview of the environmental and social impacts of 18 zero-packaging stores, as articulated by the experts and store respondents, reflecting on the performance of the food industry regarding emissions, energy and water use, packaging and food waste, nutrition, ethical trade, food safety and consumer convenience. 
Table 3 Impact of zero-packaging grocery stores on environmental and social performance of food industry based on expert interviews (Green Arrow = positive impact, Red Arrow = negative impact, $\downarrow \uparrow=$ inconclusive $/$ positive and negative impacts)

\begin{tabular}{|c|c|c|c|c|c|c|c|c|c|c|}
\hline & Emissions & Electricity & Water & $\begin{array}{l}\text { Packaging } \\
\text { Waste }\end{array}$ & $\begin{array}{l}\text { Food } \\
\text { Waste }\end{array}$ & $\begin{array}{l}\text { Healthy } \\
\text { Nutrition }\end{array}$ & $\begin{array}{l}\text { Ethical } \\
\text { Trade }\end{array}$ & $\begin{array}{l}\text { Food } \\
\text { Safety }\end{array}$ & $\begin{array}{l}\text { Customer } \\
\text { Convenience }\end{array}$ & Notes \\
\hline \multicolumn{11}{|l|}{ OPERATIONS } \\
\hline $\begin{array}{l}\text { No disposable } \\
\text { packaging }\end{array}$ & $\downarrow$ & $\downarrow$ & $\downarrow$ & $\downarrow$ & $\downarrow$ & - & - & $\downarrow$ & $\downarrow \uparrow$ & $\begin{array}{l}\text { Customers see and try the product / Portion control / Time- } \\
\text { intensive / Higher risks for food contamination }\end{array}$ \\
\hline $\begin{array}{l}\text { No processed or frozen } \\
\text { food }\end{array}$ & $\downarrow$ & $\downarrow$ & $\downarrow$ & $\downarrow$ & - & $\uparrow$ & - & $\uparrow$ & $\downarrow \uparrow$ & $\begin{array}{l}\text { Cooking skills required / Shorter FSC / Less refrigeration } \\
\text { needed / Lifestyle change needed }\end{array}$ \\
\hline 300-1500 Products & $\downarrow$ & $\downarrow$ & - & - & - & $\uparrow$ & - & - & $\downarrow \uparrow$ & Smaller stores -> less emissions / inconvenient \\
\hline $\begin{array}{l}\text { Perishing foods are } \\
\text { donated or processed } \\
\text { into meals }\end{array}$ & $\downarrow$ & $\downarrow$ & $\downarrow$ & - & $\downarrow$ & - & - & - & $\uparrow$ & $\begin{array}{l}\text { Stores with catering steer product demand / Portion control } \\
\text { might reduce food waste in households }\end{array}$ \\
\hline Trained Staff & - & - & - & - & $\downarrow$ & $\uparrow$ & - & 个 & $\uparrow$ & $\begin{array}{l}\text { Increased customer knowledge about nutrition, balanced } \\
\text { diets and handling of food }\end{array}$ \\
\hline \multicolumn{11}{|l|}{ LOGISTICS } \\
\hline No Warehouses & $\downarrow$ & $\downarrow$ & - & $\downarrow$ & - & - & - & - & - & Only one store-chain has warehouses \\
\hline $\begin{array}{l}\text { Delivery Service by Bike } \\
\text { or E-Vehicles }\end{array}$ & $\downarrow$ & $\downarrow$ & - & - & - & - & - & - & - & Reduces fossil fuel consumption \\
\hline $\begin{array}{l}5 \text { stores focus on } \\
\text { regionality }\end{array}$ & $\downarrow \uparrow$ & $\downarrow \uparrow$ & - & $\downarrow$ & - & - & $\uparrow$ & $\uparrow$ & - & $\begin{array}{l}\text { Shorter Distances / non-seasonal foods need refrigerated } \\
\text { storage or energy-intensive greenhouse production }\end{array}$ \\
\hline $\begin{array}{l}\text { Transport of big bags or } \\
\text { reusable containers }\end{array}$ & $\downarrow$ & $\downarrow$ & $\downarrow$ & $\downarrow$ & - & - & - & - & - & $\begin{array}{l}\text { Prevention of packaging waste at end-consumer and partly- } \\
\text { fully at retail-level / Could increase truck load but reusable } \\
\text { containers might weigh more }\end{array}$ \\
\hline \multicolumn{11}{|l|}{$\begin{array}{l}\text { MARKETING AND } \\
\text { SALES }\end{array}$} \\
\hline No brands & - & - & - & - & - & $\uparrow$ & $\uparrow$ & $\downarrow$ & $\downarrow \uparrow$ & $\begin{array}{l}\text { No misleading marketing / No promotion of more } \\
\text { consumption / No information about cooking or storage }\end{array}$ \\
\hline $\begin{array}{l}\text { Honesty and } \\
\text { Transparency }\end{array}$ & - & - & - & - & - & - & $\uparrow$ & $\uparrow$ & $\uparrow$ & Increases trust of customers / Facilitates food safety \\
\hline
\end{tabular}


Information on

Websites and Events

Increases trust and knowledge of customers

\section{PROCUREMENT}

In Big Bags or Reusable

Containers

2 fully and 5 partly organic stores

1 fully and 4 partly regional stores
Reduces long-term material use and emission of production No packaging or product standards for farmers and suppliers

(Arguably) decreases environmental impacts of agricultural production

Support of local small farmers / Possible agricultural diversification/ Shorter FSC 


\section{Discussion}

2 This study aimed to analyse the operation of zero-packaging grocery stores;

3 find out their interactions with FSC actors and influences they have on them;

4 and ultimately assess their environmental and social impacts. We extended

5 Porter and Kramer's (2006) value chain framework in order to identify

6 processes through which social and environmental benefits emerge. The study

7 considered the operation, logistics, marketing and sales as well as procurement

8 functions of zero-packaging stores in order to assess their social and

9 environmental performance in comparison to conventional supermarkets.

10 Following a discussion of their performance to reduce food and packaging 11 waste, resource use and increase social benefits, we analyse their unique characteristics compared to more established food retail concepts such as ethical and organic food. Then we identify alternative pathways through which zero-packaging could become more mainstream and thus drive more sustainable consumption and production patterns. While we recognise the importance of regional contexts in shaping the emergence and success of potential pathways, the broad similarities in impacts of FSCs in different markets (see e.g. Stenmarck et al., 2016) give confidence that the conclusions drawn here are applicable across a wide range of international contexts.

\subsection{Food and packaging waste}

22 Their most obvious positive environmental impact is the material and emissions 23 savings through renouncing disposable packaging - not only at consumer and retail end, but also by influencing the packaging practices of suppliers. Yet, packaging does not significantly contribute to the greenhouse gas emissions of the food industry (Garnett et al., 2003). Moreover, Verghese et al. (2015) claim packaging saves considerable emissions due to the prevention of food waste, which is the most effective measure for minimising the environmental impact of

29 the food industry (Schmidt Rivera et al., 2014). Although not all the products 
1 available in conventional supermarkets can be offered without packaging or 2 reusable packaging, some zero-packaging stores offer up to 1500 products. On

3 the one hand, unpackaged fruits and vegetables might perish faster. On the 4 other hand, zero-packaging stores enable consumers to control the product amount they buy, whilst also being less restrictive on size or form standards for fruits and vegetables that farmers usually have to comply with. Hence, some experts suggest that packaging standards might even lead to more food waste 8 than no packaging; thus, contradicting the argument that packaging is preventing food waste. Furthermore, some of the interviewed stores are able to avoid food waste by processing and serving unsold food at integrated snack counters or catering services. This not only allows them to offer a greater variety of products that are not consumed regularly but also extends the potential reduction of food waste from consumer end to include retailer and suppliers. In summary, comparing the pros and cons of zero-packaging stores becomes rather complex and hence demands further investigation.

\subsection{Resource use and emissions}

17 Selling of fresh, limited refrigerated, less processed and more seasonal food should lead to a significant reduction in energy and water consumption and emissions, not only in the retail stores but also along the FSC as many of the manufacturing processes are excluded. While Schmidt Rivera et al. (2014) suggest home-made meals consume less energy and resources, differences in cooking practices and lifestyle choices (e.g. cooking vs roasting) make the calculation of energy needed for home cooking rather difficult. Products from small-scale producers possibly have higher emissions than products from large producers due to economies of scale, potentially reducing the benefits of these stores. On the other hand seasonal products might balance out this effect. Despite seasonal food potentially causing lower emissions, consumers are accustomed to products being available all year round. Geographical differences in climate and soil types/quality mean that the products zeropackaging stores can offer become limited if they opted to offer only seasonal and regional products. The majority of interviewed stores understand that 
1 regional products are only environmentally beneficial if they are not produced in 2 greenhouses or require excessive refrigerated storage.

3 Another factor impacting emissions is the efficiency of logistics. On the one 4 hand emissions might decrease, if less packaging results in increased 5 truckloads but could also increase due to heavier reusable containers and 6 increased backhaul transportation. Additionally, any adverse effects of missing 7 product protection, e.g. damages and food waste, need to be considered. 8 Regional products lead to shorter distances from the supplier to the store. 9 Besides lower emissions, a short supply chain enables easier and faster 10 communication and quicker response times to fluctuating demand (Reiner and 11 Trcka, 2004). However, it should be considered that the procurement at 12 suppliers was not explicitly investigated here. Hence, supply chains might 13 actually be longer than articulated by SRs and there was no data with regard to 14 the frequency of deliveries.

\section{$15 \quad \mathbf{5 . 3}$ Social impacts}

16 Zero-packaging stores return power to consumers by offering better portion 17 control and to suppliers by presenting an alternative to their conventional 18 consolidated buyers. Portion control is not only an environmental but also a 19 social benefit, as it reduces costs and avoids overconsumption. While 20 conventional supermarkets may also offer smaller portions, they simultaneously introduce more packaging and charge a higher unit price. Monkhouse and Dibb (2011, p. 22) argue that people need to be enabled to "do the right thing more easily". If people are trying to renounce plastic in their lives, zero-packaging stores will indeed simplify the process and provide an alternative and empower people to have a more sustainable and healthy lifestyle.

Another customer benefit is the improved customer service in stores and transparency about their suppliers, which could improve consumers' understanding of FSCs. Coupled with the provision of recipe boxes, these stores aim to facilitate a healthy diet. A disadvantage of unpackaged food is the lack of information regarding cooking, storage and ingredients which is usually provided on the packaging. Customers need specific knowledge and cooking 
1 skills in order to handle and prepare the food properly. Interestingly, neither 2 store owners nor experts identified missing ingredient information as a problem 3 for allergies. Compared to conventional stores, zero-packaging stores have a 4 greater need to focus on hygiene and prevent food contamination. However, several bulk stores have been successfully operating for years and meeting food safety standards does not seem to emerge as a particular challenge.

7 Some stores articulated that they are able to offer further benefits to consumers 8 via competitive prices, claiming to offer some of the products cheaper than conventional stores. As the majority of the interviewed stores prefer organic products, the prices are comparable or lower than in organic grocery stores.

11 Thus, they could make organic products available for people who usually cannot afford organic products. Although studies assert that prices of unpackaged products decrease due to lower material and marketing costs (WRAP, 2007), not all interviewed stores observe this trend. These differences might depend on the store size and the region. Additionally, only few suppliers are suitable for zero-packaging stores at the moment. If the stores reached scale and more suppliers would be able to offer bulk products, it could potentially lead to further price competition.

\subsection{Distinction from existing sustainable store concepts}

Zero-packaging grocery stores follow a model that offers a radical change and disruptive innovation. They operate at a scale close to a neighbourhood store with a more limited product variety than found in conventional supermarkets. A significant number of stores combine well-established, more sustainable retail concepts such as organic and regional sourcing. In addition to supporting local and small-scale farmers, some stores procure fair-trade products from developing countries which are common practices for many supermarkets. Even though they are far from presenting a homogenous set of practices, their unique and common characteristic is the prevention of packaging waste at the consumer end. Their conceptual and organisational business model sets a stark contrast to efficiency-driven conventional supermarkets. By enabling consumers to buy as much as they need without the allure of market offers and promotions 
1 they prevent food waste and potential over-consumption whilst encouraging a 2 varied diet. Their flexibility to use unwanted products in food counters is another 3 practice that reduces potential food waste as reported by some of the stores.

4 They provide not only information and transparency but also allow consumers to 5 change their habits and simultaneously impact the operation of suppliers and 6 producers. Indeed, in their assessment of large retailers' initiatives to reduce 7 consumers' emissions, Morgan et al. (2015) report a lack of integration across 8 individual social material contexts in order to induce change in consumer behaviour and practice. In this regard, zero-packaging stores integrate these concepts across business activities by offering individual information supported 11 by a set of institutions along the supply chain. They stand to transform the relation to and understanding of nutrition and offer quality food products for moderate prices and with less environmental impact.

\section{$14 \quad 5.5$ Transformative market potential of zero-packaging concept}

As it stands, zero-packaging stores are a 'niche' concept. Our findings point to a number of alternative pathways for zero-packaging to become more widely adopted, i.e. opening more zero-packaging stores, online shopping and adoption of this concept by conventional supermarkets. On the first pathway, our analysis reveals the presence of two kinds of zero-packaging stores. The smaller 'neighbourhood' stores which offer comparable (but not necessarily lower) prices, portion control and an improved environmental conscience. Whereas larger stores induce innovation, impact suppliers, offer a larger product range, lower prices and are comparatively convenient. Stores in the latter category are eager to develop digital tools to inform their customers of emissions they save by renouncing packaging.

Given the expected preparedness of the consumer to bring their containers, compared to making a momentarily shopping decision on the go, online shopping (Anesbury et al., 2016; Moth, 2015) can contribute to their penetration in the market. In such a system, reusable containers can be used as part of a deposit-refund system which is shown to be effective in reducing emissions (Simon et al., 2016). Two issues might be relevant for this pathway's success 
1 though: Associated energy and water use to ensure the hygiene of containers 2 and the lack of one-to-one personal interaction to provide advice to consumer 3 on using products with shorter shelf lives.

4 Given large market shares of conventional supermarkets, a pathway that can be

5 more transformative is their adoption of zero-packaging concept as previously 6 done with organic food. In his analysis of organic food penetrating the 7 mainstream, Smith (2006) documents how the initial conception of organic 8 farms serving local communities with seasonal food became fragmented over 9 time. High compatibility of organic food with technologies, materials and 10 practices of conventional supermarkets, coupled with interests and positive 11 perceptions of multiple actors (such as soil associations, consumers, and 12 environmental organisations) drove conventional supermarkets to integrate 13 organic food into their product portfolios. Cost, availability and convenience 14 demands of conventional system have fragmented its ethos and resulted in 15 organically produced ingredients to be imported across the globe, processed 16 and packaged as with other (non-organic) goods. Yet, parallel to this, the more 17 complete organic vision continued its survival at niche level via farmer markets 18 or organic box scheme suppliers. Smith (2006) reveals that the higher the 19 degree of mainstream compatibility of a niche, the higher the chance of it being 20 adopted and integrated into standard routines and practices. The corollary is 21 that this compatibility blunts the transformative potential of niche. This example 22 can give us clues into which factors of the incumbent market regime are likely to 23 support or limit the niche development of the zero-packaging concept for 24 different business processes as articulated by Porter and Kramer (2006) (Table 25 4). 
1 Table 4. Comparing the adoption of organic food versus zero-packaging concept

\section{2 by conventional supermarkets}

\begin{tabular}{|c|c|c|}
\hline & $\begin{array}{l}\text { Adoption of organic food } \\
\text { concept }\end{array}$ & $\begin{array}{l}\text { Adoption of zero-packaging } \\
\text { concept }\end{array}$ \\
\hline Operations & $\begin{array}{l}\text { Handling, processing and } \\
\text { packaging practices were } \\
\text { able to continue as before } \\
\text { other than changing the } \\
\text { source of the ingredients. }\end{array}$ & $\begin{array}{l}\text { Operations in conventional } \\
\text { supermarkets are largely } \\
\text { dependent on packaging. } \\
\text { Hence, substantial changes are } \\
\text { required. }\end{array}$ \\
\hline Procurement & $\begin{array}{l}\text { Suppliers are assessed by } \\
\text { certification bodies. }\end{array}$ & $\begin{array}{l}\text { Zero-packaging needs to be } \\
\text { ensured throughout the supply } \\
\text { chain. Appropriate certification } \\
\text { schemes are currently non- } \\
\text { existent. }\end{array}$ \\
\hline Logistics & $\begin{array}{l}\text { Compatible since packaging } \\
\text { is similar to non-organic } \\
\text { food. }\end{array}$ & $\begin{array}{l}\text { Particular challenges for } \\
\text { product protection and logistics } \\
\text { activities such as transport and } \\
\text { sorting. Changes may be } \\
\text { required. }\end{array}$ \\
\hline Marketing and sales & $\begin{array}{l}\text { Higher costs but clear } \\
\text { environmental and social } \\
\text { benefits as articulated by a } \\
\text { multitude of actors. Shorter } \\
\text { lifetime of products as } \\
\text { additives and preservatives } \\
\text { are not included. No } \\
\text { changes in the way } \\
\text { consumers buy or use the } \\
\text { products. }\end{array}$ & $\begin{array}{l}\text { Might need staff in order to } \\
\text { provide consumer advice and } \\
\text { engagement. }\end{array}$ \\
\hline
\end{tabular}

4 Our analysis reveals a larger number of practices and routines of conventional

5 retailers that are more of a limiting than supporting nature compared to the 6 adoption of organic food. We identify in particular three issues that might 7 significantly impede this concept penetrating the mainstream. Shopping, 8 cooking and consuming non-packaged food requires consumers to get used to 9 products with shorter shelf lives and no use-by-date reminders. The second 10 issue relates to the traceability of non-packaged goods and the distribution of 11 associated costs and benefits across the FSC. Not only were the benefits of 12 organic food clear and supported by a multitude of actors but its introduction did 13 also not require changes in distributor, retailer and consumer routines and 14 practices. As the higher cost of organic food production was passed down to the 15 consumer directly, it did not pose a threat to conventional supermarkets' 
1 business model in terms of promotions and market offers. However removing 2 packaging starting from the producers will require the distributors and retailers 3 to develop new handling, processing and logistics operations. It is also likely to 4 require more consumer facing staff to provide advice and help. Even though the 5 system benefits of zero-packaging are relatively transparent, it is not clear 6 which actors would actually reap the benefits or incur new costs. If it costs a 7 producer less to send bulk amounts but the retailer incurs higher costs due to 8 new handling procedures, should the consumer pay more or less? Currently 9 some large retailers in the UK offer some fruits and vegetables packaged and non-packaged side by side. There are some organic stores with a bulk department ${ }^{5}$ operating in North America as well. As our research did not analyse these operations, we do not have any evidence on how these practices are aligned with the ethos of the zero-packaging concept.

14 Another issue linked to the supply chain is the quantification of environmental benefits. Whilst stricter environmental laws and regulations on the amount of waste retailers create can incentivise the supermarkets to reduce packaging waste, the fact that it is distributed across the supply chain makes it difficult to identify responsibilities. Institutional arrangements for eco-branding and thirdparty certification (Chkanikova and Lehneron, 2015), similar to that for organic products, can give consumers assurance and evidence on what benefits they are getting in return for a less convenient shopping experience.

22 Despite these limitations, even though store respondents do not view cost 23 savings as their main message, communication of cost-saving advantages to consumers might support zero-packaging stores in gaining access to a wider customer base. Garnett (2011) points out that consumer could use their savings to purchase more expensive food (meat) or non-food products, which could possibly have a higher environmental impact ('rebound effect'). In this regard, adherence to transparent pricing schemes and avoiding consumer confusion is

\footnotetext{
${ }^{5}$ There are over 450 whole food stores operating in the US, Canada and the UK (URL http://www.wholefoodsmarket.com/department/bulk, accessed 15.7.2016). There are similar, but smaller independent stores operating in other European countries (Appendix A3).
} 
1 paramount as breaches of consumer law can result in enforcement action ${ }^{6}$ and 2 may influence the reputation of the retailers.

3 Conventional grocery stores, non-governmental organisations and government 4 initiatives try to change consumer behaviour by providing additional information 5 (often on packaging) whilst industry performance is usually influenced by the 6 introduction of new laws and regulations (WRAP, 2014). Another factor that will 7 support the growth of zero-packaging stores is the adoption of stricter laws and 8 regulations on the amount of packaging waste generated across the supply 9 chain.

10 A factor that will carry a larger weight on the expansion and adoption of zero11 packaging concept is increasing consumer demand for more transparency and sustainability along the FSC supply chain and an appreciation of freshly made food over processed food. Table 5 offers a summary of the barriers and drivers zero-packaging is facing in gaining wider adoption.

Table 5. Barriers and drivers for the expansion of zero-packaging concept

\begin{tabular}{|l|l|}
\hline \multicolumn{1}{|c|}{ Barriers } & \multicolumn{1}{c|}{ Drivers } \\
\hline$-\quad \begin{array}{l}\text { Lifestyle change and cooking skills } \\
\text { required of consumers }\end{array}$ & $-\begin{array}{l}\text { Consumer demand more transparency } \\
\text { and sustainability }\end{array}$ \\
\hline$-\begin{array}{l}\text { Suppliers have to change their } \\
\text { practices }\end{array}$ & $-\begin{array}{l}\text { Price advantage due to avoided cost in } \\
\text { production and disposal }\end{array}$ \\
\hline$-\quad \begin{array}{l}\text { Fundamental change of marketing and } \\
\text { consumer-brand relationship }\end{array}$ & $-\begin{array}{l}\text { Facilitating low-impact and healthy } \\
\text { consumer behaviour }\end{array}$ \\
\hline$-\quad$ Establishing trust in food safety & $-\quad \begin{array}{l}\text { Competitive advantage regarding } \\
\text { environmental behaviour }\end{array}$ \\
\hline$-\quad$ Pressure of main market player & \\
\hline
\end{tabular}

17 How these drivers and barriers might influence the emergence and success of 18 the suggested alternative pathways is very much dependent on the regional 19 context, including the regulatory framework and legislations, affluence of the

\footnotetext{
${ }^{6}$ Potentially misleading special offers, unit pricing, price-matching schemes and changing pack sizes were the subject of recent a review by the UK Competition and Markets authority (URL https://www.gov.uk/government/news/cma-recommends-changes-to-help-shoppers-insupermarkets, accessed 6.7.2016).
} 
1 market and customer preferences. For example, in contrast to the experts' view 2 on customers not wanting to pay more for a less convenient shopping 3 experience, a study shows that more than $80 \%$ of German customers would 4 buy non-packaged goods: $35 \%$ in zero-packaging stores, $63 \%$ in supermarkets with a bulk department (PwC, 2015). The most important reason is to protect the environment, followed by portion control. A third of them would be willing to pay a higher price. To what degree similar views will be echoed in other countries is a big unknown as Germany is well-known for its discounter and cheap food prices whereas quality of food is potentially more important in e.g. France or Spain. On the other hand, our small sample size does not allow separating out the influence of regional contexts on the operation of the zeropackaging concept.

\section{Conclusions and Further Research}

The aim of this study was to analyse the prospects of zero-packaging grocery stores to present a resource efficient and socially valuable alternative to traditional food retailers. Zero-packaging stores renounce disposable packaging and influence suppliers to adapt reusable packaging practices. As food waste is the biggest negative externality of the FSC, the main advantage over conventional stores is their potential to reduce food waste at supplier, retail and consumer end. Utilising unsold food and focusing on seasonal and unprocessed food avoids energy-intensive storage, manufacturing, and disposal processes. By supporting small-scale farmers, zero-packaging stores may shorten supply chains and increase overall transparency of the FSC. Operating with unpackaged food requires close collaboration with hygiene regulation offices to prevent food safety issues. Barriers to healthier diets are reduced by offering portion control, healthy food for lower prices and increasing knowledge by employing trained staff and carrying out events about sustainability and food topics. Hence, the zero-packaging concept holds considerable potential to improve the environmental and social performance of the food industry. Yet, this comes at the expense of consumer convenience due to more time-consuming shopping and a limited product range. 
1 Our analysis points to three potential pathways by which these stores penetrate 2 the mainstream. The first pathway comprises the expansion of zero-packaging 3 stores. We identify two distinct types of stores: small stores resembling the 4 classical 'corner shops', versus more innovative ones developing new operation systems to increase consumer convenience. The second pathway involves online delivery. A third and more transformative pathway would be the adoption

7 of this concept by conventional supermarkets.

8 This qualitative, exploratory research has two main limitations. Firstly, most of 9 the stores are relatively young and therefore do not have empirical data to 10 quantify their advantages or disadvantages in terms of avoided packaging, 11 waste and emissions. Secondly, the expert interviews conducted provide an 12 initial reflection on the issues at hand and might not be representative or 13 provide full coverage. Nonetheless, this study gives first insights into the operation of zero-packaging grocery stores and the impacts that zero-packaging grocery stores have on the environmental and social performance of the food industry. Future studies can aim to shed light on which characteristics of regional contexts might support or limit the emergence and operation of zeropackaging stores and how this varies across different countries. As our study presents zero-packaging stores operating in European markets, further studies can look into other international contexts such as Asia, Australia and Africa. Another knowledge gap is around consumer attitudes and behaviours, including how frequently they shop, their socio-economic demographics, and their motivational factors (Chekima et al., 2016). Our research did not explore whether customer loyalty is positively correlated with increased contact with store personnel. Further research can analyse how no packaging impacts the logistics along FSC and how that varies by seasons. Quantitative studies are also needed to measure the impact: e.g. generation and prevention of packaging waste and food waste (at supplier, store and consumer level), as well as impacts on local economies and small producers. This could be done through longitudinal studies in companies planning to reduce packaging or also

31 through archival research on previously implemented changes to packaging practices. The resulting findings could be instrumental in finding the optimal 
1 zero-packaging model for consumers and thus also support social research 2 about changing consumer behaviour for a more sustainable lifestyle.

3 


\section{ACKNOWLEDGEMENTS}

We would like to express our gratitude to all the stores and experts for participating in the research and providing us with all required information.

\section{REFERENCES}

Akkerman, R., Farahani, P., Grunow, M., 2010. Quality, safety and sustainability in food distribution: a review of quantitative operations management approaches and challenges. OR Spectr. 32, 863-904. doi:10.1007/s00291010-0223-2

Anesbury, Z., Nenycz-Thiel, M., Dawes, J., Kennedy, R., 2016. How do shoppers behave online? An observational study of online grocery shopping. J. Consum. Behav. 15, 261-270. doi:10.1002/cb

Azevedo, S.G., Carvalho, H., Cruz Machado, V., 2011. The influence of green practices on supply chain performance: A case study approach. Transp. Res. Part E Logist. Transp. Rev. 47, 850-871. doi:10.1016/j.tre.2011.05.017

Baldwin, C.J., 2015. The 10 Principles of Food Industry Sustainability. John Wiley \& Sons, Ltd, Chichester, UK. doi:10.1002/9781118447697

Bartl, A., 2014. Moving from recycling to waste prevention: a review of barriers and enables. Waste Manag. Res. J. Int. Solid Wastes Public Clean. Assoc. ISWA. doi:10.1177/0734242X14541986

BMELV, 2010. Die deutsche Landwirtschaft Leistungen in Daten und Fakten. Berlin.

Canning, P., Charles, A., Huang, S., Polenske, K.R., Waters, A., 2010. Energy Use in the U.S. Food System.

Chekima, B., et al., 2016. Examining green consumerism motivational drivers: does premium price and demographics matter to green purchasing? J. Clean. Prod. doi: 10.1016/j.jclepro.2015.09.102

Chkanikova, O., Lehner, M. 2015. Private eco-brands and green market development: towards new forms of sustainability governance in the food retailing. J. Clean. Prod. doi: 10.1016/j.jclepro.2014.05.055.

Coley, D., Howard, M., Winter, M., 2009. Local food, food miles and carbon emissions: A comparison of farm shop and mass distribution approaches. Food Policy 34, 150-155. doi:10.1016/j.foodpol.2008.11.001 
Co-op, 2004. Shopping with Attitude. Manchester.

Davis, M.A., 2013. The Science of Meat Quality. John Wiley \& Sons, Inc., Oxford, UK. doi:10.1002/9781118530726

Defra, 2014a. Food Statistics Pocketbook 201385.

Defra, 2014b. Food Statistics Pocketbook 2014.

DEFRA, 2010. The path towards a zero waste economy: waste review launched [WWW Document]. URL https://www.gov.uk/government/news/the-pathtowards-a-zero-waste-economy-waste-review-launched (accessed 5.19.15).

DEFRA, 2006. Food Industry Sustainability Strategy, Department for Environment, Food and Rural Affairs. London.

Edwards, J.B., McKinnon, A.C. and Cullinane, S.L., 2010. Comparative analysis of the carbon footprints of conventional and online retailing: A "last mile" perspective. International Journal of Physical Distribution \& Logistics Management, 40(1/2), pp.103-123.

FoodDrinkEurope, 2012. ENVIRONMENTAL SUSTAINABILITY VISION TOWARDS 2030 Achievements, Challenges and Opportunities.

Fox, T., Vorley, B., 2004. Stakeholder Accountability in the UK Supermarket Sector Final Report of the "Race to the Top " Project 1-40.

Garnett, T., Carnegy, V., Ellen, N., Fox, T., Healy, S., Oram, J., Rowley, J., Cox, S., 2003. Wise Moves: Exploring the relationships between food, transport and carbon dioxide, Transport 2000 Trust. London.

Gevaers, R., Van de Voorde, E., Vanelslander, T., 2014. Cost Modelling and Simulation of Last-mile Characteristics in an Innovative B2C Supply Chain Environment with Implications on Urban Areas and Cities. Procedia - Soc. Behav. Sci. 125, 398-411. doi:10.1016/j.sbspro.2014.01.1483

Hayn, D., Empacher, C., Halbes, S., 2005. Trends und Entwicklungen von Ernährung im Alltag - Ergebnisse einer Literaturrecherche. Frankfurt am Main.

Hill, A., Hill, T., 2012. Operations management, $3^{\text {rd }}$ edition. Palgrave Macmillan.

ISTF, 2016. Organic food. Institute of Food Science \& Technology, London, UK. URL http://www.ifst.org/knowledge-centre/information-statements/organicfood (accessed 13.7.2016) 
J Sainsbury plc, 2016. How many products does Sainsbury's Supermarkets sell? [WWW Document]. URL http://www.j-

sainsbury.co.uk/extras/faqs/media/how-many-products-does-sainsburyssupermarkets-sell/ (accessed 1.17.16).

James, S.J., James, C., 2010. The food cold-chain and climate change. Food Res. Int. 43, 1944-1956. doi:10.1016/j.foodres.2010.02.001

Koelmans, A. a., Gouin, T., Thompson, R., Wallace, N., Arthur, C., 2014. Plastics in the marine environment. Environ. Toxicol. Chem. 33, 5-10. doi:10.1002/etc.2426

Kuhn, H., Sternbeck, M.G., 2013. Integrative retail logistics: An exploratory study. Oper. Manag. Res. 6, 2-18. doi:10.1007/s12063-012-0075-9

Monkhouse, C., Dibb, S., 2011. Making Sustainable Lives Easier, Society. London.

Morgan, E., Tallontire, A., Foxon, T.J., 2015. Large UK retailers' initiatives to reduce consumers' emissions: a systematic assessment. J. Clean. Prod. doi:10.1016/j.jclepro.2015.08.069

Moth, D., 2015. UK online retail sales to reach £52.25bn in 2015 [WWW Document]. URL https://econsultancy.com/blog/66007-uk-online-retailsales-to-reach-52-25bn-in-2015-report/ (accessed 6.29.16).

Mwatsama, M., Stewart, L., 2005. Food Poverty and Health.

N24, 2015. Handel darf Lebensmittelreste nicht wegwerfen.

Naik, B.S., Ward, M., Godfrey, G., Hanifan, G., 2010. Simultaneous Sustainability and Savings.

Pimbert, M., Tran-Thanh, K., Deléage, E., Reinert, M., Trehet, C., Bennett, E., 2006. Farmers' Views on the Future of Food and Small Scale Producers. Summary of an Electronic Conference (14.4.-1.7.2005).

Porter, M.E., Kramer, M.R., 2006. Strategy \& Society - The link between competitive advantage and corporate social responsibility. Harv. Bus. Rev.

PwC, 2015. Verpackungsfreie Lebensmittel - Nische oder Trend?

PricewaterhouseCoopers, Frankfurt am Main.

Quested, T., Ingle, R., Parry, A., 2013. Household Food and Drink Waste in the United Kingdom 2012, WRAP. Banbury. 
Raynolds, L.T., 2000. Re-embedding global agriculture: The international organic and fair trade movements. Agriculture and human values, 17(3), pp.297-309. doi:10.1023/A:1007608805843

Reiner, G., Trcka, M., 2004. Customized supply chain design: Problems and alternatives for a production company in the food industry. A simulation based analysis. Int. J. Prod. Econ. 89, 217-229. doi:10.1016/S09255273(03)00054-9

Risch, S.J., 2009. Food Packaging History and Innovations. J. Agric. Food Chem. 57, 8089-8092. doi:10.1021/jf900040r

Robson, C., 2002. Real World Research, 2nd ed. Blackwell Publishing, Malden.

Roy, P., Nei, D., Orikasa, T., Xu, Q., Okadome, H., Nakamura, N., Shiina, T., 2009. A review of life cycle assessment (LCA) on some food products. J. Food Eng. 90, 1-10. doi:10.1016/j.jfoodeng.2008.06.016

Rubin, H.J., Rubin, I.S., 2005. Qualitative Interviewing - The art of hearing data, 2nd ed. Sage Publications, Thousand Oaks.

Sandelowski, M., Barroso, J., 2007. Handbook for Synthesizing Qualitative Research. Springer Publishing Company, New York.

Saunders, C., Barber, A., 2008. Carbon Footprints, Life Cycle Analysis, Food Miles: Global Trade Trends and Market Issues. Polit. Sci. 60, 73-88. doi:10.1177/003231870806000107

Schmidt Rivera, X.C., Espinoza Orias, N., Azapagic, A., 2014. Life cycle environmental impacts of convenience food: Comparison of ready and home-made meals. J. Clean. Prod. 73, 294-309.

doi:10.1016/j.jclepro.2014.01.008

Seebauer, S., Kulmer, V., Bruckner, M., Winkler, E., 2015. Carbon emissions of retail channels: the limits of available policy instruments to achieve absolute reductions. J. Clean. Prod. doi:10.1016/j.jclepro.2015.02.028

Sim, S., Barry, M., Clift, R., Cowell, S.J., 2007. The relative importance of transport in determining an appropriate sustainability strategy for food sourcing. Int. J. Life Cycle Assess. 12, 422-431. doi:10.1007/s11367-0060259-3

Simon, B., Amor, M. Ben, Földényi, R., 2016. Life cycle impact assessment of beverage packaging systems: Focus on the collection of post-consumer bottles. J. Clean. Prod. 112, 238-248. doi:10.1016/j.jclepro.2015.06.008 
Smith, A., 2006. Green niches in sustainable development: The case of organic food in the United Kingdom. Environ. Plan. C Gov. Policy 24, 439-458.

doi:10.1068/c0514j

Smith, B.G., 2008. Developing sustainable food supply chains. Philos. Trans. R. Soc. Lond. B. Biol. Sci. 363, 849-861. doi:10.1098/rstb.2007.2187

Sneddon, S., Brophy, N., Li, Y., MacCarthy, J., Martinez, C., Murrels, T., Passant, N., Thomas, J., Thistlethwaite, G., Tsagatakis, I., Walker, H., Thomson, A., Cardenas, L., 2015. Greenhouse Gas Inventories for England, Scotland, Wales and Northern Ireland: 1990-2008.

Steedman, P., Falk, T., 2009. From A to B - A snapshot of the UK food distribution system.

Stenmarck, A., Jensen, C., Quested, T., Moates, G., 2016. Estimates of European food waste levels. URL http://www.eufusions.org/phocadownload/Publications/Estimates\%20of\%20European $\% 2$ 0food\%20waste\%20levels.pdf (accessed 19.6.2016).

Langton, S. 2015. Resilience and structural change in English agriculture, in: AUK Seminar 2015. URL https://www.gov.uk/government/uploads/system/uploads/attachment data/f ile/442567/aboutstats-aukpresentations-07jul15.pdf (accessed 17.7.2016)

Tassou, S.A., Kolokotroni, M., Gowreesunker, B., Stojceska, V., Azapagic, A., Fryer, P., Bakalis, S., 2014. Energy demand and reduction opportunities in the UK food chain. Proc. ICE - Energy 167, 162-170. doi:10.1680/ener.14.00014

Theguardian, 2015. Plastic bag usage down $78 \%$ since introduction of $5 p$ charge, says Tesco. URL https://www.theguardian.com/environment/2015/dec/05/plastic-bag-usagedown-78-since-introduction-of-5p-charge-says-tesco (accessed 15.7.2016).

Thompson, R.C., Moore, C.J., vom Saal, F.S., Swan, S.H., 2009. Plastics, the environment and human health: current consensus and future trends. Philos. Trans. R. Soc. B Biol. Sci. 364, 2153-2166. doi:10.1098/rstb.2009.0053

UNEP, 2010. Waste and Climate Change.

Verghese, K., Lewis, H., Lockrey, S., Williams, H., 2015. Packaging's Role in Minimizing Food Loss and Waste Across the Supply Chain. Packag.

Technol. Sci. 28, 603-620. doi:10.1002/pts.2127 
Vermeulen, S.J., Campbell, B.M., Ingram, J.S.I., 2012. Climate Change and Food Systems. Annu. Rev. Environ. Resour. 37, 195-222. doi:10.1146/annurev-environ-020411-130608

Weber, C.L., Matthews, H.S., 2008. Food-Miles and the Relative Climate Impacts of Food Choices in the United States. Environ. Sci. Technol. 42, 3508-3513. doi:10.1021/es702969f

Wilson, T., 2007. The " food miles" fallacy. Inst Public Aff. Rev 59(2), 41-43.

Wognum, P.M., Bremmers, H., Trienekens, J.H., Van Der Vorst, J.G. a J., Bloemhof, J.M., 2011. Systems for sustainability and transparency of food supply chains - Current status and challenges. Adv. Eng. Informatics 25, 65-76. doi:10.1016/j.aei.2010.06.001

Wood, Z., Butler, S., 2015. Tesco cuts range by 30\% to simplify shopping. The Guardian, https://www.theguardian.com/business/2015/jan/30/tesco-cutsrange-products (accessed 13.7.2016)

WRAP, 2015. Estimates of food and packaging waste in the UK grocery retail and hospitality supply chain.

WRAP, 2007. Self-Dispensing Systems - Commercial Feasibility Study.

WRAP (Waste and Resource Action Programme), 2014. Plastic Packaging [WWW Document]. URL http://www.wrap.org.uk/content/recycling-plasticpackaging (accessed 2.10.15).

Yakovleva, N., 2007. Measuring the Sustainability of the Food Supply Chain: A Case Study of the UK. J. Environ. Policy Plan. 9, 75-100. doi:10.1080/15239080701255005 


\section{APPENDIX A}

Table A 1 List of all operating zero-packaging grocery stores $(x=$ all products, 0 = mixture, / = no information)

\begin{tabular}{|c|c|c|c|c|c|c|}
\hline \multirow{2}{*}{ Name } & \multirow{2}{*}{ Location } & \multirow{2}{*}{$\begin{array}{l}\text { Opening } \\
\text { Date }\end{array}$} & \multicolumn{3}{|c|}{ Products } & \multirow[b]{2}{*}{ Business Model } \\
\hline & & & Regional & Organic & Range & \\
\hline \multicolumn{7}{|l|}{ Austria } \\
\hline Frida & Hohenhems & 01.03 .2015 & 0 & $x$ & / & $\begin{array}{l}\text { Café incl. Breakfast and } \\
\text { Lunch, Information } \\
\text { about Suppliers on } \\
\text { Website }\end{array}$ \\
\hline $\begin{array}{l}\text { Lunzers Maß- } \\
\text { Greißlerei }\end{array}$ & Vienna & 26.02.2015 & $x$ & 0 & ca. 400 & Café \\
\hline \multicolumn{7}{|l|}{ Belgium } \\
\hline $\begin{array}{l}\text { Content } \\
\text { Robuust! The } \\
\text { Zero Waste } \\
\text { Shop }\end{array}$ & Antweerp & $2014 ?$ & $x$ & $x$ & / & $\begin{array}{l}\text { Lunch corner, Café, } \\
\text { Workshops, Lectures, } \\
\text { Events, Information } \\
\text { about suppliers on } \\
\text { website } \\
\text { Including blog, DIY } \\
\text { products (e.g. } \\
\text { toothpaste) }\end{array}$ \\
\hline \multicolumn{7}{|l|}{ Czech Republic } \\
\hline Opobchod & Prague & / & / & / & / & \\
\hline Bezobalu & Prague & 2014 & 0 & / & / & $\begin{array}{l}\text { First year non-profit to } \\
\text { test the concept. }\end{array}$ \\
\hline \multicolumn{7}{|l|}{ Germany } \\
\hline Unverpackt & Kiel & 01.02 .2014 & 0 & 0 & $>400$ & $\begin{array}{l}\text { Coffee Corner, Tasting } \\
\text { Events, Consultation } \\
\text { Workshops }\end{array}$ \\
\hline $\begin{array}{l}\text { Original } \\
\text { Unverpackt }\end{array}$ & Berlin & 13.09 .2014 & 0 & 0 & 400 & $\begin{array}{l}\text { Consultation } \\
\text { Workshops }\end{array}$ \\
\hline Freikost Deinet & Bonn & 01.05 .2015 & $x$ & $x$ & 300 & $\begin{array}{l}\text { Café with sandwiches, } \\
\text { soups, coffee, tea / } \\
\text { supportive community } \\
\text { - membership fee } \\
\text { guarantees lower } \\
\text { prices / Get-to-Know } \\
\text { the Supplier - Events }\end{array}$ \\
\hline
\end{tabular}




\begin{tabular}{|c|c|c|c|c|c|c|}
\hline \multirow{2}{*}{ Name } & \multirow{2}{*}{ Location } & \multirow{2}{*}{$\begin{array}{l}\text { Opening } \\
\text { Date }\end{array}$} & \multicolumn{3}{|c|}{ Products } & \multirow[b]{2}{*}{ Business Model } \\
\hline & & & Regional & Organic & Range & \\
\hline \multicolumn{7}{|l|}{ Germany } \\
\hline Unverpackt & Mainz & 08.06 .2015 & $x$ & $x$ & 999 & $\begin{array}{l}\text { Talks and Events about } \\
\text { Sustainability / } \\
\text { Consultation Workshop }\end{array}$ \\
\hline Lose & Dresden & 01.04 .2015 & 0 & $x$ & / & Coffee Corner \\
\hline $\begin{array}{l}\text { Annas } \\
\text { Unverpacktes }\end{array}$ & Heidelberg & 18.06 .2015 & 0 & $x$ & $>150$ & \\
\hline $\begin{array}{l}\text { Regional und } \\
\text { unverpackt }\end{array}$ & $\begin{array}{l}\text { Schwäbisch } \\
\text { Gmünd }\end{array}$ & 01.07 .2015 & $x$ & 0 & / & \\
\hline \multicolumn{7}{|l|}{ Italy } \\
\hline Effecorta & Milano & & 0 & 0 & / & $\begin{array}{l}\text { Events with Suppliers } \\
\text { and/or about cooking }\end{array}$ \\
\hline NegozioLeggero & 12 Stores & 2009 & 0 & $x$ & $>1500$ & $\begin{array}{l}\text { Supported by Research } \\
\text { Institute Ecologos, } \\
\text { Bike-Deliveries }\end{array}$ \\
\hline \multicolumn{7}{|l|}{ Spain } \\
\hline Graneria Sala & Barcelona & 1885 & / & o & / & \\
\hline Granel & $\begin{array}{l}\text { Barcelon/ } \\
\text { Ibiza/Vic }\end{array}$ & 2011 & $x$ & $x$ & / & $\begin{array}{l}\text { Deliveries are managed } \\
\text { by an external } \\
\text { distribution company, } \\
\text { Promotion of slow food } \\
\text { concept }\end{array}$ \\
\hline \multicolumn{7}{|l|}{ United Kingdom } \\
\hline Beunpackaged & London & $2006 / 2015$ & - & $x$ & $50-100$ & $\begin{array}{l}\text { Started in } 2007 \text {, } \\
\text { expanded after } 5 \text { years } \\
\text { including a café \& bar, } \\
\text { but closed a year later. } \\
\text { Reopened in } 2015 \text { in } \\
\text { the store Planet } \\
\text { Organic. }\end{array}$ \\
\hline
\end{tabular}




\begin{tabular}{|c|c|c|c|c|c|c|}
\hline \multirow{2}{*}{ Name } & \multirow{2}{*}{ Location } & \multirow{2}{*}{$\begin{array}{l}\text { Opening } \\
\text { Date }\end{array}$} & \multicolumn{3}{|c|}{ Products } & \multirow[b]{2}{*}{ Business Model } \\
\hline & & & Regional & Organic & Range & \\
\hline \multicolumn{7}{|l|}{ Belgium } \\
\hline Content & Leuven & 2014 & $\mathrm{x}$ & 0 & / & $\begin{array}{l}\text { Lunch corner, Café, } \\
\text { Workshops, Lectures, } \\
\text { Events, Information } \\
\text { about suppliers on } \\
\text { website }\end{array}$ \\
\hline $\begin{array}{l}\text { Robuust! The } \\
\text { Zero Waste } \\
\text { Shop }\end{array}$ & Antweerp & $2014 ?$ & $\mathrm{x}$ & $\mathrm{x}$ & / & $\begin{array}{l}\text { Including blog, DIY } \\
\text { products (e.g. } \\
\text { toothpaste) }\end{array}$ \\
\hline \multicolumn{7}{|l|}{ Canada } \\
\hline Strictly Bulk & Toronto & 1987 & / & / & / & Small coffee corner \\
\hline
\end{tabular}

Table A 2 List of zero-packaging grocery stores under construction A1 List of zero-packaging grocery stores under construction

\begin{tabular}{ll}
\hline Store Name & Location \\
\hline Liebe und Lose & Innsbruck, Austria \\
Holis Market & Linz, Austria \\
Tütenlos & Köln, Germany \\
LoLa & Hannover, Germany \\
OHNE & Munich, Germany \\
Louise genießt & Erfurt, Germany \\
Bag \& Buy & Utrecht, Netherlands \\
\hline
\end{tabular}


Table A 3 Selection of zero-packaging departments in grocery stores

\begin{tabular}{ll}
\hline Store Name & Location \\
\hline Bio-Laden Familie Matzer & Graz, Austria \\
\hline Genussplatzl Wasserwald & Linz, Austria \\
\hline Veganladenkollektiv & Berlin, Germany \\
\hline Holtorf Feinkost \& & Bremen, Germany \\
Kolonialwaren & Hamburg, Germany \\
\hline 12 Monkey - Vegankrams & Hannover, Germany \\
\hline Calenberger Bioladen & Schortens, Germany \\
\hline Mercado Mundial & Berlin, Germany \\
\hline Biosphäre & Hannover, Germany \\
\hline Bittersüß & Würzburg, Germany \\
\hline Kräuterwelt & Leipzig, Germany \\
\hline Veganz & Groningen, Netherlands \\
\hline Obgeweckt Noord & Zürich, Switzerland \\
\hline Chornlade Idaplatz & \\
\hline Chornlade Limmatplatz & Büland \\
\hline
\end{tabular}

